\title{
Rogers, Constructivism and Jurisprudence: Educational Critique and the Legal Curriculum
}

\author{
Dr Paul Maharg
}

\begin{abstract}
The focus of this chapter initially is the educational writings of Carl Rogers and the relevance of them to contemporary legal education. Rogers could be described as an extreme example of pragmatist philosophy in action, focusing as he does upon the primacy of experience, and can therefore be cited as one sympathetic to many of the aims of Dewey in the American pragmatist tradition. His work is part of the tradition of humanist education, yet his views also sit well beside a number of contemporary educational and cognitive research directions, all of which have relevance for the teaching and learning of law. In this chapter I shall put forward two arguments. First, I shall argue that Rogers, seldom cited in legal educational literature, has relevance for those involved with legal skills education. Perhaps more significantly, his views on the differences between teaching and learning re-surface in contemporary theory on learning processes, especially constructivist theories and phenomenographical methodologies, which similarly focus on the learning experience. Secondly, and on a wider front, I would argue that both Rogers and constructivism lead us to consider issues which are not only at the heart of educational debates, but are the concerns of jurisprudence as well. In this respect I hope that the chapter will illustrate the overlap between jurisprudence and legal education, and the extent to which educational issues (particularly epistemological ones) are also jurisprudential ones.
\end{abstract}




\section{Carl Rogers and education}

One of the earliest and most important of Rogers' statements on education is his 'Personal Thoughts on Teaching and Learning'. ${ }^{1}$ First delivered in 1952 at a conference in Harvard during a session on 'Classroom Approaches to Influencing Human Behavior', and widely circulated, then published in 1957, this controversial piece was extensively re-published, not only in collections of Rogers' work, but in major collections of educational literature. ${ }^{2}$

The text is a radical educational version of what has come to be known as Rogerian, or person-centred modes of learning. It is declaratory, a manifesto of sorts, though uttered in a private voice, and ending with the very antithesis of a peroration. It is not an essay but a conference paper and was not subsequently revised for publication. It is barely more than three pages in length; it begins with puzzlement and ends abruptly by asking his readers to reflect on the effect his argument has had on them. 'Argument' is not quite the right word, suggesting continuous prose and an array of rhetorical devices appropriate to that form. There is no formal set of arguments, no logical pattern in extended prose: aphorisms are perhaps the closest form to describe the statements Rogers makes, which at times are almost like Wilde's epigrams on teaching and learning. ${ }^{3}$ The text belongs to the tradition of aphoristic literature in philosophy, literature and education - Bacon's Essays rather than the Bacon of the Novum Organon, the later rather than the earlier Wittgenstein, Adorno's Minima Moralia rather than the systematic work of Horkheimer. Yet, as with the aphoristic tradition generally, the brevity of the argumentative unit belies the depth of perception which lies in each aphorism, and the extent to which the network of sayings or statements build upon each other to give a coherent view of the educational process. The form, in other words, says much about the content of the text.

When first delivered at an educational conference in Harvard in 1952, the paper provoked a highly critical debate among the teachers and educationalists present. It is not difficult to see why this was so, given that at the time, the dominant paradigm in educational psychology was behaviourism. Four years before Miller's important paper on memory and the information processing model, and twelve years before Chomsky's famous rebuttal of behaviourist linguistics (Miller 1956, Chomsky 1964), Rogers rejected the core assumptions of the behaviourist project quite explicitly in this paper. He does so by distinguishing between 'learning' on the one hand, and 'behaviour' on the other, and opposing the behaviourist reduction of the learning context to stimulus-response theory (s-r) is denied in points b. and d.:

b. It seems to me that anything that can be taught to another is relatively inconsequential and has little or no significant influence on behavior.

\section{$[\ldots]$}

\footnotetext{
${ }^{1}$ Rogers $1957 . \quad F u r t h e r$ reference to this text is included in the body of the chapter.

2 See, eg, Rogers 1969, 151-6

3 See for example Wilde 1894
} 
d. I have come to feel that the only learning which significantly influences behavior is self-discovered, self-appropriated learning. (p.302) ${ }^{4}$

Having stated this he goes on to explore what are for him the consequences of taking seriously 'self-discovered, self-appropriated learning'. This leads him to a rejection of explicit teaching which seeks to 'influence behavior' in favour of a model of facilitative communication in which the teacher becomes a learner primarily, either individually or in groups. This model, based upon facilitation, leads Rogers to fairly radical conclusions regarding some familiar landmarks in the curriculum. As he confesses, with some irony, '[it] is when I realize the implications that I shudder a bit at the distance I have come from the commonsense world that everyone knows is right' (p.303). Teaching, examinations, grades, credits, degrees and the exposition of conclusions - all this would be abolished. At this point, Rogers breaks off - 'I do not want to become too fantastic' (p.303).

The points Rogers makes appear at first to have little relevance to legal education. It is difficult to imagine a curriculum in law which is not based upon examinations and grades, while the essence of the legal case-book is the 'exposition of conclusions', which Rogers regards as being of little worth to learners. But Rogers has a lot to say about the experience of learning which is relevant legal learning. In point $h$., for instance, he declares that the results of his own attempts to teach were that either 'damage was done' or 'nothing significant occurred' (p.302). As a result, point i. goes on to state 'I realize that I am only interested in being a learner, preferably learning things that matter, that have some significant influence on my own behavior'(p.302)..$^{5}$ Rogers is taking issue here with the concept of 'teaching' as heavily didactic, and with teaching as transmission of knowledge. Whether or not we agree that the results of this type of teaching are either insignificant or damaging, his point applies profoundly to student motivation, as the research on this subject confirms. ${ }^{6}$ It also applies to continuing professional development education where, if the learning is carried out using authentic activities, then the experience of point $j$. in Rogers' argument comes about: 'I find it very rewarding to learn' (p.302). Points k. and I. go on to explore what it is that makes learning rewarding. Once again, Rogers eschews the s-r model of grades and penalties, and examines his own experience of learning:

k. I find that one of the best, but most difficult, ways for me to learn is to drop my own defensiveness, at least temporarily, and to try to understand the way in which his experience seems and feels to the other person.

I. I find that another way of learning for me is to state my own uncertainties, to try to clarify my puzzlements, and thus get closer to the meaning that my experience actually seems to have. (pp.302-3)

\footnotetext{
4 Emphasis in original

${ }^{5}$ Emphasis in original

${ }^{6}$ See, for example, Paris \& Turner 1994
} 
Point k. finds its parallel, in legal education, within much of the literature on legal skills learning, particularly on client interviewing and counselling. ${ }^{7}$ Topics such as dropping the defensiveness of the mask of expertise and engaging with and negotiating the client's fears and anxieties is central to much of this literature, and it leads on to an acknowledgement of the role of point $I$. in professional learning (Brayne 1998). Point I. also has relevance for undergraduate legal learning. Rogers draws attention to what has become known as 'metacognition', the process by which learners reflect on and control their learning. ${ }^{8}$ It is one way of articulating what Schön, Eraut, Barnett and other educationalists were later to explore as aspects of 'knowledge-in-action'. ${ }^{9}$

It is significant that the only reference Rogers makes to another author is to Søren Kierkegaard: what Rogers gives us is in one sense an existential view of education, one which relies heavily on his firmly held view that teachers and therapists achieve most when they are attentive, as facilitators, to the learning experience, rather than overt teachers. ${ }^{10}$ Such a view of education is present in the rest of his educational and clinical writings. As he says in his essay 'The Interpersonal Relationship in the Facilitation of Learning', 'if we focused on the facilitation of learning -- how, why, and when the student learns, and how learning seems and feels from the inside -- we might be on a much more profitable track' (Rogers 1967b, p.16). ${ }^{11}$

This experiential approach is of a piece with his view of the therapeutic relationship. As he says in On Becoming a Person:

'[e]xperience is, for me, the highest authority. The touchstone of validity is my own experience. No other person's ideas, and none of my own ideas, are as authoritative as my experience. ... My experience is not authoritative because it is infallible. It is the basis of authority because it can always be checked in new primary ways. In this way its frequent error or fallibility is always open to correction.' (Rogers 1967, p.26)

This passage is interesting because of the contrast Rogers draws. First there is the assertion of the primacy of individual experience. But Rogers does not leave it there: if he did, he would be open to the accusation of naïve solipsism. He goes on to distinguish between experience as authority, and experience as authoritative in an objective way. Clearly he rejects the latter. Indeed (and with a typically Rogerian inversion) it is because experience is the 'highest authority' that it is fallible, and must be 'always open to correction'.

\footnotetext{
7 See for example Le Brun and Johnstone 1994, Maughan and Webb 1995, Webb and Maughan, 1996, Brayne, Duncan and Grimes, 1998.

${ }^{8}$ Flavell (1976) describes it as follows: 'Metacognition refers to one's knowledge concerning one's own cognitive processes or anything related to them, e.g., the learning-relevant properties of information or data'. See also Forrest-Pressly et al. 1985, and McAleese 1985

${ }^{9}$ For instance Schön 1983, Schön 1987, Eraut 1994, Barnett 1992

${ }^{10}$ In the retrospective notes added to this essay in his later volume Freedom to Learn, Rogers commented that '[i]f the style, and the attempt to be as honest as possible, smacks of Kierkegaard, this is not a coincidence. I had spent much of my time on this trip [to Mexico, where the paper was written] reading, digesting and appreciating his work' (Rogers 1969, p.151). In these comments Rogers also notes that this paper was the first in which he articulated for himself the distinctions between teaching and learning.

${ }^{11}$ Reprinted in Kirshenbaum and Henderson 1989,304-22, p.320
} 
The passage is in one sense a more radical version of Dewey's pragmatic emphasis upon experience. Rogers acknowledged the influence of Dewey and Kilpatrick in his early seminal period at Rochester (Kirschenbaum 1979, p.95). Indeed Rogers acknowledges the debt to Dewey in one of his own favourite essays, 'The necessary and sufficient conditions of therapeutic personality change' when he describes the crucial concept of unconditional positive regard: '[i]t means that there are no conditions of acceptance [of the client], no feeling of "I like you only if you are thus and so." It means a 'prizing' of the person, as Dewey has used that term' (Rogers 1957b, p.100). ${ }^{12}$

This essay, as with much of Rogers' work, concentrates on ways in which the client (not the 'patient': the lexical substitution is acute in describing the change of relationship) can be prized by being accepted and listened to. Empathy plays a key role. As he describes it in another book,

[empathy] includes communicating your sensings of [the client's] world as you look with fresh and unfrightened eyes at elements of which the individual is fearful. It means frequently checking with him/her as to the accuracy of your sensings, and being guided by the responses you receive. You are a confident companion to the person in his/her inner world. (Rogers 1980, p.142)

For Rogers, what mattered was not so much the categorising of illness and mental condition, and the belief of objective reality which underlay such practice, but the perception of reality as possessed by the client. prizing and empathy were key affective and experiential components of the relationship between counseller and client in which, in contrast to much current therapeutic practice, Rogers was able to explore the 'inner world' of the client precisely by being not an alienating and authoritative expert, but a 'confident companion'. The language of this extract is of a piece with the extract above where Rogers writes of 'checking' the fallibility of his own experiential perception.

It is a phenomenology of sorts, a deep concern with the way that the world is perceived, and how those perceptions affect subsequent behaviour and perception of experience. All this is present, if not on the page then certainly in the conceptual structures that underlie the aphorisms, in 'Personal Thoughts on Teaching and Learning'. As we shall see, they are not too far removed from aspects of contemporary educational theory, in particular constructivism.

\section{Constructivism}

Such is the debate about its central concepts that constructivism could perhaps be construed as a body of theories about the learning processes. ${ }^{13}$. Perhaps most basic is the idea that learning is an active process within which learners are constantly constructing thought which always springs from their own experience and structures of thought. Constructivism is intensely learner-centred: what learners know, what they need to know next and how they might begin to understand assimilate such new knowledge is focus of constructivist design.

The concept is not confined to educational psychology. More broadly, it is part of a general trend in the humanities and social sciences towards exploring the place

\footnotetext{
12 Reprinted in Kirschenbaum and Henderson 1989, 219-35, p.225

13 The literature is considerable. For an introduction, see Bransford and Vye 1989, Forman and Pufall 1989, Honebein, Duffy and Fishman 1993, Lebow 1993.
} 
of connectionist (Rummelhart and McClelland 1986), social constructivist (Bruffee 1986), antifoundationalist (Phillips 1995, Winn 1993) and similar sociocultural approaches to knowledge and society (Confrey 1995). In terms of educational psychology, there is an irony here, of course: few theories of educational design have provoked such powerful conceptual responses, both for and against, from such a variety of communities: psychologists, educationalists, philosophers, narratologists, and specialised educationalists from almost every professional educational field. But if the theory and its consequences are controversial, there is general agreement on the three assumptions underlying almost all constructivist positions, which are as follows.

\section{i. Knowledge Construction and disciplinary communities.}

Constructivists emphasise that knowledge is not received from external sources, but is generated, often by contact with external stimuli, from individual understanding. From this knowledge base, and the changes brought about within it by constantly-evolving experience, stems understanding of the world. There is thus no guarantee that there will be any direct correspondence between an external concept presented to the individual, and the concept as it is understood by the individual. ${ }^{14}$

But if individuals all interpret the world differently, then constructivists require to account for commonly-held and accepted understandings of percepts. They do so by relying on the social negotiation of meaning, which is 'supported by collaborative construction of knowledge' (Jonassen et al 1993, p.233). Both points, constructivists would argue, hold important consequences for learning and teaching. First, if all individuals interpret and learn differently, teachers require to learn how they can support such difference in learning. Secondly, if social negotiation of meaning within disciplinary communities is important for the transfer of meaning, then students require to be inducted into what one might regard as the syntax of the community, its attitudes, logical forms, genres, procedures and belief systems, as well as what one might regard as its substantive content. Thirdly, co-operation, rather than isolation, in learning becomes a powerful heuristic.

If individual understanding arises only from individual perception, then it would appear difficult for constructivism to account for the transfer of learning from an understanding of individual percept (eg an example or instance of a rule) to an understanding of the more generic precept (that is, the rule itself). ${ }^{15}$ This is an important criticism of any learning theory, particularly one which puts so much emphasis, as constructivism does, upon individual understandings of the perceptual world. Constructivists counter it by giving a phenomenological account of the inter-relations of individual experiences. Jonassen et al, for instance, cites Hannabuss (1992) for whom 'understandings are part of a referential hierarchy in which personal "stories" subsume concepts which in turn subsume propositions' (p.235). If there are no meaningful contexts to a learning event, then the move from percept to precept is made more difficult for learners for whom there is therefore no referential context. The environment of learning thus takes on added importance: case-studies, realia, simulations, clinical environments are examples of these. This argument, however, has not satisfied

\footnotetext{
${ }^{14}$ There is a clear parallel here between this point of view and Rogers' view concerning the exposition of conclusions to learners

${ }^{15}$ For a full discussion of this with reference not to constructivism but to situated cognition, see Laurillard 1992, pp.19-28
} 
the critics of constructivist theory, many of whom, such as Laurillard, are sceptical of the claims made about the power of contextual learning to move from percept to precept. It could be argued that this point in the constructivist argument is the most contentious, and the one most open to rebuttal. ${ }^{16}$

\section{ii. Constructivist and Rogerian theory.}

Many of the traits outlined above, of course, are not unique to constructivism alone. They are shared by other learning strategies: situated cognition, cognitive apprenticeships and realia are some examples of this (Grabinger and Dunlap 1995). ${ }^{17}$ Constructivism differs in that it strongly links the epistemological grounds of the theory to classroom heuristics. Many instructional design approaches to knowledge acquisition acknowledge the variability of learning styles and experience that students bring to the task of education; but do not give central place in their design to these variations. Robert Gagné's instructional design is an example of this which, as Steve Draper rightly observes, is 'strictly top down. It takes instructional objectives and subdivides them in a top down fashion, ending up with a set of small items, for each of which a separate instructional action is taken. This is like the design methods that used to be taught in computer science, but are now largely discredited even there.' (Draper 1997). Draper's criticism of Gagné, in a Web IT Forum discussion with one of Gagné's proponents, Dave Merrill, casts useful light on the constructivist debate. Draper points out that a top down model 'only works in domains where each part of the problem can be solved independently, and the solution to one part has no effect on the solution to another part.' (ibid). But even here there are difficulties with instructional designs which are overly programmatic: 'if an instructor convinces himself they are independent, this does not make it any more likely that they are independent in the mind of the learner... It just means the instructor is designing for himself, not for the learner.' Draper goes on to point out that instructional actions as well as knowledge items 'may have multiple effects' and that therefore 'the relationships here are many to many, and no top down design procedure can cope.' (ibid).

It has to be said that Draper is not arguing the constructivist corner here; but his arguments against forms of instructional design are a useful illustration of the power of the constructivist position, starting as it does from strong and transparent presuppositions about the epistemological status of learning and understanding. From this springs the extent to which the mediational role of individual experience is emphasised, and the consequent use of heavily contextualised teaching and learning strategies. In this sense it could be argued that, more than other learning theorists, constructivists follow through the logic of starting from what the learner knows: this includes what the learner knows of the learning process.

\footnotetext{
${ }^{16}$ Petraglia (1998) discusses this in depth. He recasts the problem as the constructivists' need for 'authenticity' in learning

${ }^{17}$ It is interesting to note that Dewey's use of the concept of 'situation' is close in a number of respects to contemporary situationist theory. His concept of the self is one where 'the self is not something ready-made, but something in continuous formation through choice of action'(Dewey 1961 p.408). This concept of selfhood is based upon the interaction of objective and subjective factors within experience, and as a result, Dewey advocated not a dualism of the two concepts, but the dialectic of the two, the essence of this dialectic being the social continuity as held in memory between different episodes: '[d]ifferent situations succeed one another. But because of the principle of continuity something is carried over from the earlier to the later ones' (Dewey 1938 p.37). In many respects this is similar to Rogers' concept of the primacy of experience.
} 
It also takes into account what the teacher knows of the learning process. Constructivist learning requires careful curriculum planning, from general to specifics and between each component of the curriculum. This is one reason why Draper (no constructivist, though sympathetic to constructivist concerns) argues against top-down design procedures:

I am not against setting explicit goals systematically, and indeed refining them down into small pieces. But I am interested in whether existing design methods then draw the false though apparently sensible inference that the pieces can then be addressed independently. A good test is whether any piece of instruction relates to more than one objective: in reality I sometimes learn more than one thing from a single learning event. (ibid)

Here as elsewhere in this debate Draper appeals to a hermeneutic sense of the learning experience. This is not a naïve holism, but a sense of interconnection within the elements that go to make up the learning experience: a learning ecology of sorts, where the quality of the learning environment is crucial.

There are clear similarities between what Rogers advocates in his radical essay, and the constructivist understanding of the learning process. Both question the value of direct teaching; and both advocate, in Rogers' terms, 'self-discovered, self-appropriated learning' and the replacement of overtly didactic instructional strategies with the 'facilitation of significant learning'. ${ }^{18}$ Both rely on an epistemology which emphasises the process of knowing and learning rather than the object of knowledge to be learned.

Between these two positions in the field of educational enquiry, therefore, there can be drawn a number of lines of similarity, a conceptual genealogy which crosses the disciplines of psychology (person-centred counselling and cognitive science) and education, and traditions of thought within those disciplines. At a more basic level, there are also similarities of epistemological concern. Both Rogers and constructivists would agree on the necessity for educational theory to take account of epistemological method and construct: Rogers, because his epistemology is grounded less in theory and much more in experience and practice, as is constructivist learning design, and constructivism because of the felt need of constructivists to return to the fundamental question of what constitutes learning. As a result of the epistemological enquiry they carry out, both Rogers and constructivists reach conclusions about educational method that are often regarded as controversial. There are of course differences in methodology and in practice between Rogers and constructivist educational practice. Nevertheless, we can see a similar move to enquire at a deep level into the nature of understanding and the status of knowledge; followed by a movement from epistemological enquiry to putting the results of this enquiry into practice in the classroom. This characteristic movement has two important implications for legal education which we shall consider below: the relationship of educational theory to practice, and the working-out of this relationship within the legal curriculum.

\section{Theory and practice: the symbiotic relationship}

If the changes advocated by Rogers and constructivism are to come about, it is necessary first, for all legal educators, no matter what their status and role within

\footnotetext{
18 Kirschenbaum and Henderson 1989, pp.302, 305
} 
the law school, to be aware of the epistemological and educational theories which their practice as law teachers embody; and for this reflexive awareness to have an effect on their practice as educators. ${ }^{19}$ Such a symbiosis of theory and practice is precisely what a number of educationalists have advocated should occur if quality in teaching and learning is to improve. Paul Ramsden for example, drawing upon research carried out by, among others Margaret Balla, Gloria Dall'Alba and Elaine Martin into lecturers' structures of theory and beliefs about teaching, has proposed that, broadly speaking, teachers in higher education hold one of three generic theories of the role of the teacher. Theory one is 'Teaching as telling or transmission', where teaching is defined as 'the transmission of authoritative content or the demonstration of procedures' (Ramsden 1992, p.111). Theory two, transitional between one and three, is 'Teaching as organising student activity' where student learning is seen as problematic, and where teaching is 'seen as a supervision process involving the articulation of techniques designed to ensure that students learn' (ibid., p.113). Theory three, 'Teaching as making learning possible', treats teaching and learning as complementary activities, 'a process of working co-operatively with learners to help them change their understanding' (ibid., p.114). As Ramsden observes, this theory is based on a 'different epistemology' from theories one and two: '[i]t is recognised that knowledge of the subject content is actively constituted by the learner' (ibid., p.114). As a result, theory three 'extends the understanding of teaching so that it becomes embedded in the nature of subject knowledge and the nature of how it is learned' (ibid., p.116). Ramsden clearly views theory three as superior to theories one and two, and he is in no doubt that the adoption of theory three is a necessary precondition for higher quality in teaching and learning:

it [theory three] represents the goal towards which all efforts at improving teaching in higher education should be directed. Changing lecturers' understanding of teaching is a necessary condition for improving teaching in higher education. (ibid, p.117)

If theory is important to practice, how might legal educators go about research into their practice? Rogers provides little in the way of direction here. Instead, we could apply to an important line of contemporary research in educational psychology which stems from the same phenomenological roots as Rogers' work, namely phenomenography. This movement in educational psychology grew out of dissatisfaction with existing forms of research into learning, and with the cognitive models which stemmed from of this research. It was based in centres in Sweden (University of Göteborg) and the UK (Lancaster, Edinburgh, Surrey universities), and is associated with (in Sweden) Ference Marton, Lars-Owe Dahlgren, Roger Säljö, Lennart Svensson, and in the UK, Noel Entwistle, Diana Laurillard, Paul Ramsden and Dai Hounsell. It has been described as 'hard-nosed phenomenology' (Marton et al 1997, p.vii), and consists of intensive interviews with students which are analysed, and sometimes followed up by statistical analysis of posttest results. ${ }^{20}$

\footnotetext{
${ }^{19}$ It is important that they start from their practice: as Schön and Argyris have pointed out, the theoretical implications of a practitioner's actual practice can be at odds with the theory adduced by the practitioner when reflecting on that practice (Schön 1983)

${ }^{20}$ For careful analysis of phenomenographical method, see Marton and Booth 1997, chapter six, 'The Idea of Phenomenography', and in particular the section entitled 'Methods of phenomenographic research -- constituting the object of research', pp.129-35.
} 
The results of this research often go to the heart of the student experience of higher education in a way that is strikingly similar to Rogers' insights. This will be clear if we take one example of phenomenographical research, namely Marton and Säljö's work on students' reading strategies. Marton and Säljö set out to discover what students actually did and felt when they were trying to learn from texts. Students were interviewed, and then an iterative procedure of category analysis was used to separate different items and examine the relationships within the overall '"pool of meanings"' (Marton et al 1997, pp.42-3). The reasons for the differences between student performance, they discovered, lay within students' self-perceptions as they read the texts - one group saw themselves as 'empty vessels ... to be filled with words on the page', while the second group saw themselves as 'creators of knowledge who [had] to use their capabilities to make critical judgements' (ibid., p.43). This is illustrated by quotes from the interviews. From the first group -

"... the only thing I was thinking about was that I'd got to hurry. What happened was that I read a couple of sentences and then I didn't remember what I'd read because I was thinking all the time, 'I've got to hurry to get this done' ... I kept on thinking that I'd got to remember what I'd just read, but (then I would wonder) 'How am I going to remember this now'. 'I won't remember anything' is what I thought more or less in several places.' (ibid, p.43)

The above extract is a clear example of what would later be known generally as surface learning. ${ }^{21}$ In this example we can see researchers trying to understand how students study by researching the experience of learning. They do so by examining the relations between students' conceptions of what a learning task demands of them. As a result, many phenomenographers argue that one of the most efficient ways of improving student learning is to make the learners' conceptions explicit to them: '[t]he aim is for them to become conscious of the fact that there are different conceptions of the phenomena in question, and see what the conceptions are' (Marton and Ramsden 1988, p.277). The approach to learning is strikingly similar to Rogers' approach to learning quoted in points k. and I. above (p.XXX), all the more so because phenomenology, in its findings and methodology, is applicable not only to the context of student learning but to teachers and their situation as well. If, as Ramsden asserts, changing lecturers' understanding of teaching is necessary to improve teaching, then one way to do so is to promote the basic concepts of what we might call Rogerian metacognition (point I. above) and phenomenological methodology. The phenomenological emphasis on the learning experience, the curiosity about what this entails, a refashioning of approaches to knowledge and how it can be learned most effectively -- epistemological issues such as these are seen as crucial by many educationalists. As Laurillard put it, '[i]nculcating an appropriate conception of learning, or a desirable epistemology, is not an issue peculiar to the use of educational technology. Clearly, it is fundamental to any kind of teaching' (p.214). And in the Introduction to her book she declares:

The system must change. ... Teachers need to know more than just their subject. They need to know the ways it can come to be understood, the ways it can be misunderstood, what counts as understanding: they need to know how individuals experience the subject. But they are neither required nor enabled to know these things. Moreover, our system

\footnotetext{
${ }^{21}$ Marton sees a paradox at the heart of this type of awareness of failure: ' $t \mathrm{t}$ ]he students often have the feeling that they will not remember, just because they are trying so hard to remember ... (This most extreme form of concentrating on the surface of the presentation, characterised by a failure to learn due to over-anxiety to perform well, has been called hyperintention)' (ibid, p.44)
} 
of mass lectures and examinations ensures they will never find them out. $($ pp.3-4) 22

Laurillard's last statement is particularly acute. Impediments to change are not merely personal: they are systemic and cultural within the university system and within the culture of a discipline as it is transmitted within a university.

\section{Rogers, constructivism and Jurisprudence}

This brings us to our second point. If it is the case that change is thwarted not merely within the university system, but within the culture and attitudes of individual disciplines, then it makes sense that critique of this culture should be carried out not merely by educationalists such as Ramsden and Laurillard, operating from within their own disciplinary lines of research, but by historians, psychologists, philosophers, literary critics and lawyers, all working within their own disciplines and across disciplines. Within law, there has recently been critique of traditional legal educational methods and attitudes. This has come largely from those involved in clinical programmes and skills education, as well as those involved in legal ethics, sociolegal and sociolinguistic enquiry. ${ }^{23}$ However, as we have seen, epistemology and other methodological tools such as hermeneutic enquiry are vital to many of these educational debates. These forms of enquiry are also fundamental critical methodologies in jurisprudence, which is the traditional locus for both description and critique of legal culture. They have been applied to the historical culture of legal education -- Peter Goodrich's Languages of Law is one example, a text which critically examines 'the paradigm of English law, the curriculum and method that emerged from the Inns of Court as a response to printing, to the Reformation and to the Renaissance vernacularisation of the disciplines and the sciences' (Goodrich 1990, p.20). But it may well be the case that in jurisprudence classes, students do not employ these methodological tools to examine their own experience of the law and of learning the law. I have no empirical data to support it as yet, but I would venture the proposition that legal education as a jurisprudential topos is relatively invisible, and that students' experiences of their education are rarely the focus of educational debate or jurisprudential enquiry within the classroom.

And yet there is no reason why the experience of students as they are actually studying could not be a resource upon which jurisprudential analysis could draw in order to critique law. Rogers' early paper recalls Kierkegaard, and early pragmatic debates around the concept of agency, as well as the power dynamic in any expert/novice relationship. Schön's theory of reflective practice is one of a number of more recent explorations into how (legal) professionals think in practice, and thus -- as Steven Winter and others remind us -- contributes to Realist debates on the nature of law and legal practice in society (Winter 1989). The challenge of constructivism, as Petraglia (1998) makes clear, is one that reaches to the heart of the debates surrounding antifoundationalism, rhetoric and situated cognition. Phenomenography as a research method raises questions also raised by Felstiner and Sarat, by sociolinguists and many others about how

\footnotetext{
${ }^{22}$ Others have made the same point. See for instance John Bowden, who gives the point a peculiarly Rogerian cast: ' $[w]$ hat is required is for teachers themselves to undergo a learning process -- to change their conceptions of teaching' (Bowden 1988, p.259)

${ }^{23}$ See, for example, in the UK, the work of Webb, Maughan, and Brayne, cited in the references. For US examples, see footnote 24
} 
law is presented in society and practised by lawyers. ${ }^{24}$ These are only some of the many general epistemological issues which link education to jurisprudential critique, and which lie at the heart of theories of teaching and learning and the educational debates between these theories. In their way, they contribute powerfully to our understanding of how law teachers constitute law and legal process in the law school, and thus contribute to the process and practice of law in society at large.

To make them visible, we need to continue to do what Rogers advocated over 40 years ago, namely give priority to the experience of what it is to be students and what it is to be a teacher. Sociolinguistic analysis for example, applied typically to court practice and client/lawyer interactions, could be applied to classroom interactions more often than it has been in the past; while tools of textual and critical analysis, used to interpret and decode law and legal practice, could be used to demystify the experience of legal learning and its practice. These lines of research are of a piece with Rogerian and constructivist methods. Rogers, after all, was one of the first clinicians to exploit the technologies of audio- and videotape (Rogers 1942); and constructivists, as Petraglia points out prefer to rely on what he terms 'found cognition (that is, thinking as it unfolds in natural contexts)' (Petraglia 1998, p.62). Similarly, phenomenographic research into what actually happens when students learn the law would provide more valuable data on their learning experiences than decontextualised quantitative data of tightly-controlled experimental environments. ${ }^{25}$ It is a project Rogers and constructivists would almost certainly approve.

\section{Further Reading}

\section{Rogers and education}

Kirschenbaum, Howard, and Henderson, Valerie Land (1990) (eds) Carl Rogers: Dialogues: Conversations with Martin Buber, Paul Tillich, B. F. Skinner, Gregory Bateson, Michael Polanyi, Rollo May, and Others, London: Constable

\section{Elliott-Kemp, John, Carl Rogers (1982) The Effective Teacher: A Person-centred} Development Guide, Sheffield: PAVIC Publications

For a useful introduction to the subject of existentialism and education, see David E. Denton (1974) ed., Existentialism and Phenomenology in Education: Collected Essays, New York: Teachers College Press

\footnotetext{
${ }^{24}$ The literature on this is extensive. See for example Sarat 1991; Felstiner and Sarat 1988, 1992, 1995; Cunningham 1992; Kearns and Sarat 1994.

25 This applies as much to technology in the classroom as it does to more traditional legal educational methods. See for instance the findings of the Teaching with Independent Learning Technologies (TILT) Project in the University of Glasgow, which focused on the use and evaluation of IT to show how teaching and learning could be made more productive and efficient throughout a single university. Most of their key findings as regards evaluation were carried out using observations, interviews and videotaping as well as pre- and post-test questionnaires and quizzes. This broadly phenomenographic approach to learning evaluation led them to conclude, amongst other points, that '[s]ituational factors are critical - the role of the courseware within the course, its integration with other teaching components, the availability and use (and usefulness) of other learning resources: the influence of individual and social variables.' (TILT 1997)
} 


\section{Constructivism:}

Perhaps the most recent survey of constructivist theory and history is Petraglia 1998, cited below. Key statements of theoretical positions are contained in Jonassen, David, Mayes, Terry, McAleese, Ray (1993), and Grabinger, Scott R. and Dunlap, Joanna C. (1995), all cited below. The last article also has the advantage of giving a number of examples of constructivism in practice. A useful guide to the debates is contained in Duffy, T.M., and Jonassen, D. (1992) Constructivism and the Technology of Instruction: A Conversation, Hillsdale, NJ: Lawrence Erlbaum Associates.

\section{Phenomenography:}

For a position statement and guide to methodology, Marton and Booth 1997, cited below, is probably the most recent and comprehensive. Marton et al 1997, also cited below, gives useful examples

\section{References}

Barnett, Ronald (1992) Improving Higher Education, Milton Keynes: Open University Press

Bowden, John (1988) 'Achieving change in teaching practices' in Paul Ramsden, ed., Improving Learning: New Perspectives, London: Kogan Page

Bransford, J., and Vye, N.J. (1989), 'A perspective on cognitive research and its implications for instruction' in Resnick, Laura and. Klopfer, L.E, eds, Toward the Thinking Curriculum: Current Cognitive Research, Alexandria VA, ASCD, 173-205;

Brayne, Hugh (1998) 'Counselling skills for the lawyer: can lawyers learn anything from counsellors?', The Law Teacher, 32, 2, 137-56

Brayne, Hugh, Duncan, Nigel, and Grimes, Richard (1998) Clinical Legal Education: Active Learning in Your Law School, London: Blackstone Press

Bruffee, Kenneth (1986) 'Social Construction, language and the authority of knowledge', College English, 48, 773-87

Chomsky, Noam (1964) 'A review of B.F. Skinner's Verbal Behavior', in J.A. Fodor and J.J. Katz (eds), The Structure of Language: Readings in the Philosophy of Language, Englewood Cliffs, NJ: Prentice-Hall, 547-78

Confrey, J. (1995) 'How compatible are radical constructivism, sociocultural approaches, and social constructivism?' in Steffe, L., and Gale J., eds, Constructivism in Education Mahwah, NJ: Lawrence Erlbaum Associates, 185-225

Cunningham, Clark D. (1992) 'The lawyer as translator, representation as text: towards an ethnography of legal discourse', Cornell Law Review, 77, 1298

Dewey, John (1938) Experience and Education, New York: Collier Dewey, John (1961) Democracy and Education, New York: Macmillan Draper, Stephen W. (1997, December 7) 'Constructivism and instructional design' http://www.psy.gla.ac.uk/ steve/constr.html\#my (1998, 26 July)

Eraut, Michael (1994) Developing Professional Knowledge and Competence, London: Falmer Press 
Felstiner, William L.F. and Sarat, Austin (1988) 'Law and social relations: vocabularies of motive in lawyer/client interaction', Law and Society Review, 22, 742

Felstiner, William L.F. and Sarat, Austin (1992) 'Enactments of power: negotiating reality and responsibility in lawyer-client interaction', Cornell Law Review, 77, 1447

Flavell, J. (1976) 'Metacognitive aspects of problem-solving', in Resnick, Laura, ed., The Nature of Intelligence. Hillsdale, NJ: Erlbaum Associates

Forman G. and Pufall, P.(1989) eds, Constructivism in the Computer Age, Hillsdale NJ, Lawrence Erlbaum

Forrest-Pressly, D., MacKinnon, G., and Waller, T. (1985). Metacognition, Cognition, and Human Performance. Orlando: Academic Press

Goodrich, Peter (1990) Languages of Law: From Logics of Memory to Nomadic Masks, London: Weidenfeld and Nicolson

Grabinger, Scott R. and Dunlap, Joanna C. (1995) 'Rich environments for active learning: a definition' Association for Learning Technology Journal 3, 2, 5-34

Hannabuss, S. (1992) The Representation of Effectiveness in Management: An Investigation into Concepts and Stories, doctoral dissertation, Heriot-Watt University, Edinburgh

Honebein, P.C, Duffy, T.M., and Fishman, B.J. (1993) 'Constructivism and the design of learning environments: context and authentic activities for learning', in Duffy T.M., J. Lowych, J. and Jonassen, David, eds, Designing Environments for Constructive Learning, Berlin: Springer-Verlag

Jonassen, David, Mayes, Terry, McAleese, Ray (1993) 'A manifesto for a constructivist approach to uses of technology in higher education', Duffy T.M., J. Lowych, J. and Jonassen, David, eds, Designing Environments for Constructive Learning, Berlin: Springer-Verlag

Kearns, Thomas P., and Sarat, Austin (1994) eds, The Rhetoric of Law, Ann Arbor: University of Michigan Press

Kirschenbaum, Howard (1979) On Becoming Carl Rogers, New York: Delacorte Press

Kirschenbaum, Howard and Henderson, Valerie Land (1989) The Carl Rogers Reader, Boston: Houghton Mifflin Company

Laurillard, Diana (1992) Rethinking University Teaching: A Framework for the Effective Use of Educational Technology, London: Routledge

Le Brun, Marlene and Johnstone, Richard, The Quiet (R)evolution: Improving Student Learning in Law, Sidney: The Law Book Company

Lebow, D., (1993) 'Constructivist values for instructional systems design: five principles toward a new mindset', Educational Technology Research and Development, 41 3, 4-16

McAleese, R. (1985) 'Some problems of knowledge representation in an authoring environment: exteriorisation, anomalous state meta-cognition and selfconfrontation', Programmed Learning and Education Technology, 22, 4, 299-306 
Marton, Ference, and Ramsden, Paul (1988) 'What does it take to improve learning?' in Ramsden, Paul, ed., Improving Learning: New Perspectives, London: Kogan Page

Marton, Ference, Hounsell, Dai, Entwistle, Noel (1997), eds, The Experience of Learning: Implications for Teaching and Studying in Higher Education, second edition, Edinburgh: Scottish Academic Press

Marton, Ference and Booth, Shirley (1997) Learning and Awareness, Mahwah, NJ: Lawrence Erlbaum Associates

Maughan, Caroline and Webb, Julian (1995), Lawyering Skills and the Legal Process, London: Butterworths

Miller, George (1956) 'The magical number seven, plus or minus two: some limits on our capacity for processing information', Psychological Review, 63, 81-97

Paris, Scott G., and Turner, Julianne C. (1994) 'Situated motivation' in Pintrich, Paul R., Brown, Donald R., Weinstein, Claire Ellen, Student Motivation, Cognition and Learning: Essays in Honor of Wilbert J. McKeachie, Hillsdale, NJ: Lawrence Erlbaum Associates, 213-38

Petraglia, Joseph (1998) Reality By Design: The Rhetoric and Technology of Authenticity in Education, Mahwah, NJ: Lawrence Erlbaum Associates

Phillips, D.C. (1995) 'The good the bad and the ugly: the many faces of constructivism', Educational Researcher, 24,7, 5-12

Ramsden, Paul (1992) Learning to Teach in Higher Education, London: Routledge

Rogers, Carl (1942) 'The use of electrically recorded interviews in improving psychotherapeutic techniques', American Journal of Orthopsychiatry 12, 429-34

Rogers, Carl (1957) 'Personal Thoughts on Teaching and Learning', Merrill-Palmer Quarterly, 3, Summer, 241-43

Rogers, Carl (1957b) 'The necessary and sufficient conditions of therapeutic personality change', Journal of Consulting Psychology, 21, 2, 95-103

Rogers, Carl (1967) On Becoming a Person: A Therapist's View of Psychotherapy, London: Constable

Rogers, Carl (1967b) 'The interpersonal relationship in the facilitation of learning', in Leeper, Robert, ed., Humanizing Education, Alexandria, VA: Association for Supervision and Curriculum Development, 1-18

Rogers, Carl (1969) Freedom to Learn: A View of What Education Might Become, Columbus, Ohio: Charles E. Merrill Publishing Company

Rogers, Carl (1980) A Way of Being, Boston: Houghton Mifflin

Rummelhart, D. and McClelland, J. (1986) Parallel Distributed Processing Cambridge, MA: MIT Press

Sarat, Austin (1991) 'Lawyers and clients: putting professional service on the agenda of legal education', Journal of Legal Education, 41, 43-53

Sarat, Austin, and Felstiner, W.F. (1995) Divorce Lawyers and their Clients : Power and Meaning in the Legal Process, New York: Oxford University Press, 1995. 
Schön, Donald (1983) The Reflective Practitioner, Aldershot: Avebury

Schön, Donald (1987) Educating the Reflective Practitioner, San Francisco: Jossey Bass

TILT Project (1997, 3 February) TILT Group E - Evaluation,

http://www.elec.gla.ac.uk/TILT/E-Eval.html (26 July 1998)

Webb, Julian and Maughan, Caroline (1996), eds, Teaching Lawyers' Skills, London: Butterworths

Wilde, Oscar (1894) 'A few maxims for the instruction of the over-educated', Saturday Review, 17 November

Winn, William (1993) 'A constructivist critique of the assumptions of instructional design', in Duffy, Thomas., Lowyck, J. and Jonassen, David, eds, Designing Environments for Constructive Learning, Berlin: Springer-Verlag, 189-212

Winter, Steven L. (1989) 'The cognitive dimension of the agon between legal power and narrative meaning', Michigan Law Review, 87, 2225-79 
